\begin{tabular}{|l|c|c|c|r|}
\hline $\begin{array}{l}\text { Cuadernos de Investigación Geográfica } \\
\text { Geographical Research Letters }\end{array}$ & 2017 & N $^{\circ} 43(2)$ & pp. 751-766 & $\begin{array}{r}\text { ISSN 0211-6820 } \\
\text { eISSN 1697-9540 }\end{array}$ \\
\hline
\end{tabular}

DOI: http://doi.org/10.18172/cig.3158

(C) Universidad de La Rioja

\title{
RETREAT OF THE CORDILLERA DARWIN ICEFIELD DURING TERMINATION I
}

\author{
B.L. HALL ${ }^{1 *}$, G.H. DENTON ${ }^{1}$, T.V. LOWELL ${ }^{2}$, \\ G.R.M. BROMLEY ${ }^{1}$,A.E. PUTNAM ${ }^{1}$ \\ ${ }^{1}$ School of Earth and Climate Sciences and the Climate Change Institute, \\ University of Maine, Orono, Maine, USA. \\ ${ }^{2}$ Department of Geology, University of Cincinnati, Cincinnati, Ohio, USA.
}

\begin{abstract}
During the last glaciation, the Cordillera Darwin icefield expanded northward toward the Straits of Magellan, eastward across Isla Grande de Tierra del Fuego and through Canal Beagle, and south and west across the numerous islands of southernmost Chile. Deglaciation commenced at $\sim 18 \mathrm{ka}$ during Termination I. Alpine glaciers in the Fuegian Andes also likely retreated at that time. Radiocarbon ages from the interior regions of Cordillera Darwin suggest ice in at least some locations had retreated close to its present-day limit as early as $\sim 16.5 \mathrm{ka}$. The most likely cause for such rapid ice retreat was rising atmospheric temperatures at the start of Termination I.
\end{abstract}

Retroceso de los campos de hielo de la Cordillera Darwin durante el periodo Termination I

RESUMEN. Durante la última glaciación, el campo de hielo de la Cordillera Darwin se expandió hacia el norte en dirección al Estrecho de Magallanes; hacia el este, a través de la Isla Grande de Tierra del Fuego y del Canal Beagle; y hacia el sur y oeste, a través de las numerosas islas del sur de Chile. La deglaciación comenzó hace $\sim 18 \mathrm{ka}$, durante el Termination I. Los glaciares alpinos en los Andes Fueguinos probablemente también se retiraron en ese momento. Las edades de radiocarbono de las regiones interiores de la Cordillera Darwin sugieren que el hielo en algunas localidades se había retirado cerca de su límite actual ya hacia $16.5 \mathrm{ka}$. La causa más probable de este rápido retroceso del hielo fue el aumento de las temperaturas atmosféricas al inicio del periodo Termination I.

Key words: Cordillera Darwin, Termination I, radiocarbon, deglaciation, Tierra del Fuego.

Palabras clave: Cordillera Darwin, Termination I, radiocarbono, deglaciación, Tierra del Fuego. 
* Corresponding Author: Brenda L. Hall, School of Earth and Climate Sciences and the Climate Change Institute, University of Maine, Orono, Maine, USA. E-mail address: BrendaH@maine.edu

\section{Introduction}

Cordillera Darwin ( $\sim 54^{\circ} \mathrm{S}$; Fig. 1A) is the southernmost temperate icefield on earth, with glaciers that respond sensitively to changes in temperature (Sagredo et al., 2014). Thus, a history of its fluctuations affords important clues for reconstructing temperature history, as well as the behavior of and mechanisms within the Southern Hemisphere climate system. Moreover, the region lies in a zone of strong climate gradients from the Patagonian icefields to the north $\left(\sim 37-45^{\circ} \mathrm{S}\right)$ to the Antarctic Peninsula to the south (67$70^{\circ} \mathrm{S}$ ) and thus is well-situated to aid in understanding the transition in climate between the polar high-southern latitudes and the more temperate mid-latitude regions.

We focus here on the behavior of glaciers in Tierra del Fuego, southernmost South America, during the termination of the last ice age, $18-14.5 \mathrm{ka}$. This time period, known as Heinrich Stadial 1 (HS-1) in the North Atlantic basin, coincides with the last termination in the Southern Hemisphere. Understanding the far-field effects of HS-1 and its possible role in Southern Hemisphere climate may be key for unravelling the cause of Termination I. For example, Denton et al. (2010) proposed that cold northern conditions during HS-1 led to southward movement of the Intertropical Convergence Zone and, in turn, of the southern westerly wind belts and oceanic fronts in the vicinity of Tierra del Fuego. This movement of both atmospheric and oceanic boundaries has been documented in southern South America during both glacial and interglacial times (e.g., Lamy et al., 2004, Kaiser et al., 2005; Björck et al., 2012; Moreno et al., 2012; Kohfeld et al., 2013; Vanneste et al., 2015). Anderson et al. (2009) proposed that shifting of the westerly winds over the latitude of the Drake Passage during HS-1 caused increased upwelling, which was instrumental in breaking down Southern Ocean stratification and releasing carbon dioxide to the atmosphere during the last termination.

In this paper, we begin by reviewing evidence for the extent of the Cordillera Darwin ice field at the last glacial maximum (LGM: 19-23 ka, Mix et al., 2001) and then present the current understanding of the timing and causes of deglaciation of this region during Termination I. The goal is to begin to develop an understanding of the process that set in motion the complex changes in ice extent, sea level, and landscape evolution in this region at the end of the last ice age.

Tables 1 and 2 present chronologic information used in this paper. For radiocarbon data, ages quoted in the text are in calendar years obtained from the INTCAL13 dataset and CALIB 7.0 or (in one case) the Marine13 dataset with a delta R of 140 years (Reimer et al., 2013). Original radiocarbon dates are in Table 1. Beryllium-10 surface exposure ages (Table 2) are all calculated using the Lago Argentino production rate (Kaplan et al., 2011) and the Lal (1991)/Stone (2000) scaling scheme. 
Table 1. Compilation of radiocarbon ages of basal organic remains in bog cores. Radiocarbon ages were converted to calendar years using CALIB 7 and the INTCAL13 and MARINE13 datasets (Reimer et al., 2013). Dates presented here are calculated as the midpoints of the ranges given by CALIB. Calibrations with a probability $<10 \%$ are not included. Calibrated ages may differ from those presented in the original papers due to changes in calibration datasets. Superscripts after the calibrated ages are keyed to Figure 3.

\begin{tabular}{|c|c|c|c|c|c|c|c|}
\hline Location & Core or Depth & Lab \# & Material & ${ }^{14}$ C yr B.P. & $1 \sigma$ & Cal yr B.P. & $2 \sigma$ \\
\hline \multicolumn{8}{|c|}{ Bahía Inútil/Northern Isla Dawson } \\
\hline E. Esmerelda II ${ }^{\mathrm{g}}$ & $300-312 \mathrm{~cm}$ & A-6793 & Bulk carbon & 14260 & 350 & $17240^{1}$ & 930 \\
\hline E. Cameron II $^{\mathrm{f}}$ & $420 \mathrm{~cm}$ & AA-42413 & Plant remains & 13980 & 120 & $16960^{2}$ & 410 \\
\hline E. Esmerelda II ${ }^{\mathrm{h}}$ & $312 \mathrm{~cm}$ & SRR-5143 & Bulk carbon & 13890 & 50 & $16810^{3}$ & 230 \\
\hline E. Esmerelda II ${ }^{g}$ & $300-312 \mathrm{~cm}$ & A-6814 & Bulk carbon & 13650 & 310 & $16520^{4}$ & 900 \\
\hline E. California ${ }^{\mathrm{f}}$ & $341 \mathrm{~cm}$ & AA-42414 & Plant remains & 13614 & 86 & $16440^{5}$ & 300 \\
\hline E. Esmerelda I ${ }^{g}$ & $390-400 \mathrm{~cm}$ & A- 6807 & Bulk carbon & 13425 & 310 & $16160^{6}$ & 910 \\
\hline P. Cameron ${ }^{g}$ & No information & A-6791 & Bulk carbon & 13030 & 260 & $15520^{7}$ & 860 \\
\hline Paso Garibaldi ${ }^{j}$ & $284 \mathrm{~cm}$ & A-4882 & Bulk peat & 10730 & 180 & $12570^{8}$ & 450 \\
\hline \multicolumn{8}{|c|}{ Northern Cordillera Darwin } \\
\hline P. Marinellie & MARPT-07-02_10.34-10.35m & OS-64095 & Peat macro. & 13950 & 55 & $16900^{9}$ & 250 \\
\hline P. Marinellie & MARPT-07-02_10.34-10.35m & OS-61545 & Gyttja & 14050 & 70 & $17080^{10}$ & 290 \\
\hline P. Marinellie & MARPT-07-02_10.35-10.36m & OS-64068 & Peat macro. & 13250 & 85 & $15930^{11}$ & 260 \\
\hline P. Marinellie & MARPT-07-02_10.36m & OS-61606 & Sedge & 13400 & 85 & $16110^{12}$ & 270 \\
\hline P. Marinellie & MARPT-07-02_10.36-10.38m & OS-63929 & Seeds & 13250 & 55 & $15930^{13}$ & 200 \\
\hline P. Marinellie & MARPT-07-02_10.36-10.38m & OS-64070 & Peat macro. & 13650 & 90 & $16490^{14}$ & 310 \\
\hline P. Esperanza ${ }^{e}$ & PE-07-01_8.74-8.77m & OS-61551 & Gyttja & 13350 & 65 & $16050^{15}$ & 220 \\
\hline S. Almirantazgo ${ }^{d}$ & NBP0505 JPC77_0.78m & No data & Marine carbonate* & 13650 & 70 & $15690^{16}$ & 320 \\
\hline \multicolumn{8}{|c|}{ Eastern Canal Beagle } \\
\hline Harberton $^{\mathrm{a}}$ & Harberton_10.4m & QL-4279 & unknown & 14640 & 260 & $17790^{17}$ & 650 \\
\hline Harberton ${ }^{j}$ & $998 \mathrm{~cm}$ & A-4817 & Drepanocladus & 13360 & 280 & $16080^{18}$ & 830 \\
\hline Harberton ${ }^{\mathrm{i}}$ & HAR12-PB01A/727 & GdA-2882 & Brown moss & 13335 & 59 & $16040^{19}$ & 210 \\
\hline Caleta Róbalob & Caleta Róbalo_9.1m & QL-1685 & unknown & 12730 & 90 & $15120^{20}$ & 360 \\
\hline Ushuaiac $^{c}$ & Ushuaia 2_8.2m & Beta 55681 & Bulk org. & 12430 & 80 & $14480^{21}$ & 510 \\
\hline Ushuaia $^{c}$ & Ushuaia 3_5.1m & QL-4162 & Bulk org. & 12100 & 50 & $13950^{22}$ & 160 \\
\hline Ushuaia $^{\mathrm{c}}$ & Ushuaia 1_6.7m & QL-4436 & Bulk org. & 12060 & 60 & $13920^{23}$ & 160 \\
\hline Lapataia $^{\mathrm{c}}$ & Lapataia_5.1m & RL-2001 & Bulk org. & 10080 & 250 & $11820^{24}$ & 740 \\
\hline \multicolumn{8}{|c|}{ Southern Cordillera Darwin } \\
\hline V. Holanda ${ }^{\mathrm{e}}$ & H-07-01_3.95m & OS-61638 & Peat macro. & 12550 & 60 & $14780^{25}$ & 360 \\
\hline Bahía Pía ${ }^{\mathrm{e}}$ & BL-07-16B_4.56m & OS-64237 & Peat macro. & 12350 & 120 & $14500^{26}$ & 490 \\
\hline Caleta Olla & CO-07-02_5.3m & OS-61542 & Peat macro. & 10300 & 50 & $\begin{array}{c}12090(80 \%)^{27} \\
12320(15 \%)\end{array}$ & $\begin{array}{c}160 \\
60\end{array}$ \\
\hline Bahía Pía ${ }^{e}$ & BL-07-15_1.50m & OS-61603 & Grass,sedge & 9310 & 65 & $10490^{28}$ & 190 \\
\hline
\end{tabular}

${ }^{\mathrm{a}}$ Heusser (1989a); ${ }^{\mathrm{b} H e u s s e r}$ (1989b); ${ }^{\mathrm{C}}$ Heusser (1998); ${ }^{\mathrm{d}}$ Boyd et al. (2008); ${ }^{\mathrm{H}} \mathrm{Hall}$ et al. (2013); ${ }^{\mathrm{f}} \mathrm{McCulloch}$ et al. (2005b); ' ${ }^{\mathrm{C}}$ Clapperton et al. (1995); ${ }^{\mathrm{H}} \mathrm{McCulloch}$ and Bentley (1998); ${ }^{\mathrm{i}}$ Vanneste et al., 2015; ${ }^{\mathrm{M}} \mathrm{Markgraf}$ and Huber, 2010 *A delta R of 140 years was applied to this sample, following the original authors. 
Table 2. Surface-exposure age data relating to the innermost LGM moraine belt (Belt " $D$ " of McCulloch et al., 2005b) at Bahía Inútil and deglaciation in the Fuegian Andes. Calculations are based on the Lago Argentino production rate and the time-dependent Lal (1991)/Stone (2000) scaling scheme ("Lm"). Ages for the Bahía Inútil region were recalculated from the original papers by Kaplan et al. (2011). Ages are quoted with 1-sigma internal error. Superscripts after the ages are keyed to Figure 3.

\begin{tabular}{|c|c|c|c|c|c|c|c|c|c|}
\hline Sample & Latitude & Longitude & $\begin{array}{c}\text { Elev. } \\
\text { (m) }\end{array}$ & $\begin{array}{c}\text { Thickness } \\
\text { (cm) }\end{array}$ & Shielding & ${ }^{10} \mathrm{Be}$ atoms & $\begin{array}{c}\text { Error } \\
(1 \sigma)\end{array}$ & Standard & $\begin{array}{c}\text { Age } \\
\text { (yr BP) }\end{array}$ \\
\hline \multicolumn{10}{|c|}{ Ages for the " $D$ " moraines } \\
\hline $\mathrm{BI}: \mathrm{Cl}^{\mathrm{a}}$ & -53.5781 & -69.4844 & 52 & 4.0 & 1.0 & 96455 & 6752 & S555 & $18500 \pm 1300^{29}$ \\
\hline $\mathrm{BI}: \mathrm{C}^{\mathrm{a}}$ & -53.5808 & -69.4872 & 48 & 4.0 & 1.0 & 98849 & 14234 & S555 & $19000 \pm 2800^{30}$ \\
\hline $\mathrm{BI}: \mathrm{C}^{\mathrm{a}}$ & -53.5881 & -69.4889 & 54 & 4.0 & 1.0 & 100012 & 9800 & S555 & $19100 \pm 1900^{31}$ \\
\hline SM- $02-21^{\mathrm{b}}$ & -53.5783 & -69.4852 & 60 & 0.6 & 1.0 & 107975 & 31430 & S555 & $20100 \pm 5900^{32}$ \\
\hline SM- $02-23^{b}$ & -53.5798 & -69.4781 & 56 & 2.9 & 1.0 & 92397 & 8565 & S555 & $17500 \pm 1600^{33}$ \\
\hline \multicolumn{10}{|c|}{ Ages of striated bedrock in front of cirque glaciers } \\
\hline $11-19 \mathrm{~F}^{\mathrm{c}}$ & -54.6632 & -68.3321 & 641 & 5.2 & 0.98 & 128100 & 6000 & 07KNSTD & $16670 \pm 790^{34}$ \\
\hline $11-21 A^{c}$ & -54.6613 & -68.3313 & 650 & 6.6 & 0.98 & 136500 & 6000 & 07KNSTD & $17830 \pm 790^{35}$ \\
\hline
\end{tabular}

${ }^{a}$ McCulloch et al., 2005b

${ }^{\mathrm{b}}$ Kaplan et al., 2008a

${ }^{\mathrm{c}}$ Menounos et al., 2013

\section{Regional Setting and Physiography}

Hundreds of islands from the Straits of Magellan to Cape Horn make up Tierra del Fuego (Fig. 1A, B). Cordillera Darwin, an east-west trending crystalline mountain range with peaks that surpass $2000 \mathrm{~m}$ elevation, dominates the central portion of region and forms the western peninsula of Isla Grande de Tierra del Fuego (hereafter "Isla Grande"). The mountains stretch nearly from the Pacific to the Atlantic Ocean and are bordered to the northwest by Canals Cockburn, Magdalena, and Gabriel, as well as to the north by Seno Almirantazgo and to the south by the Canals Beagle and Ballenero. The highest peaks lie near the center of the range and decrease in elevation both east and west.

Much of Tierra del Fuego lies under a wet, maritime climate strongly affected by the Southern Westerlies. Average mean annual temperature is $\sim 5^{\circ} \mathrm{C}$ (Rabassa et al., 2000). Precipitation is several meters per year near the Pacific coast and declines to less than $0.5 \mathrm{~m} / \mathrm{yr}$ in drier areas of eastern Tierra del Fuego (Lliljequist, 1970; Tuhkanen, 1992; C. Porter, unpublished data, 2007; Fontana and Bennett, 2012). This precipitation gradient has an effect both on modern snowline elevations, which rise from west to east, and on vegetation.

Cordillera Darwin, as well as the islands to the south, display a rugged landscape (Fig. 2) characterized by extensive tracts of areally scoured bedrock and dissected by fjords ( 200-400 m water depth). In contrast, eastern Isla Grande has a more rolling topography, and the landscape is dominated by LGM-aged and older moraines and glaciofluvial sediments. Relatively few constructional glacial landforms occur between the LGM moraine belt and Holocene/Late Glacial moraines located in the interior of the mountains near present-day glaciers. 


\section{Last Glacial Maximum Position}

Although well-documented in some locations, the LGM extent of the Cordillera Darwin ice field remains uncertain along most of its perimeter (Fig. 1A). Caldenius (1932) produced the earliest comprehensive map showing proposed LGM ice extent and, in many locations, this map still remains the only resource. During the LGM, ice spread from the high peaks of central Cordillera Darwin and flowed northward to the Straits of Magellan, eastward through Seno Almirantazgo to Lago Fagnano, southeastward through Canal Beagle to the junction with the Atlantic Ocean, and south and westward across the numerous islands of southern and western Tierra del Fuego to end on the continental shelf (Caldenius, 1932; Coronato et al., 1999, 2009; Rabassa et al., 2000, 2011).

Northern ice flow from Cordillera Darwin is characterized best along a flowline through Canal Whiteside to Bahia Inútil, where numerous, low-relief moraines enclose

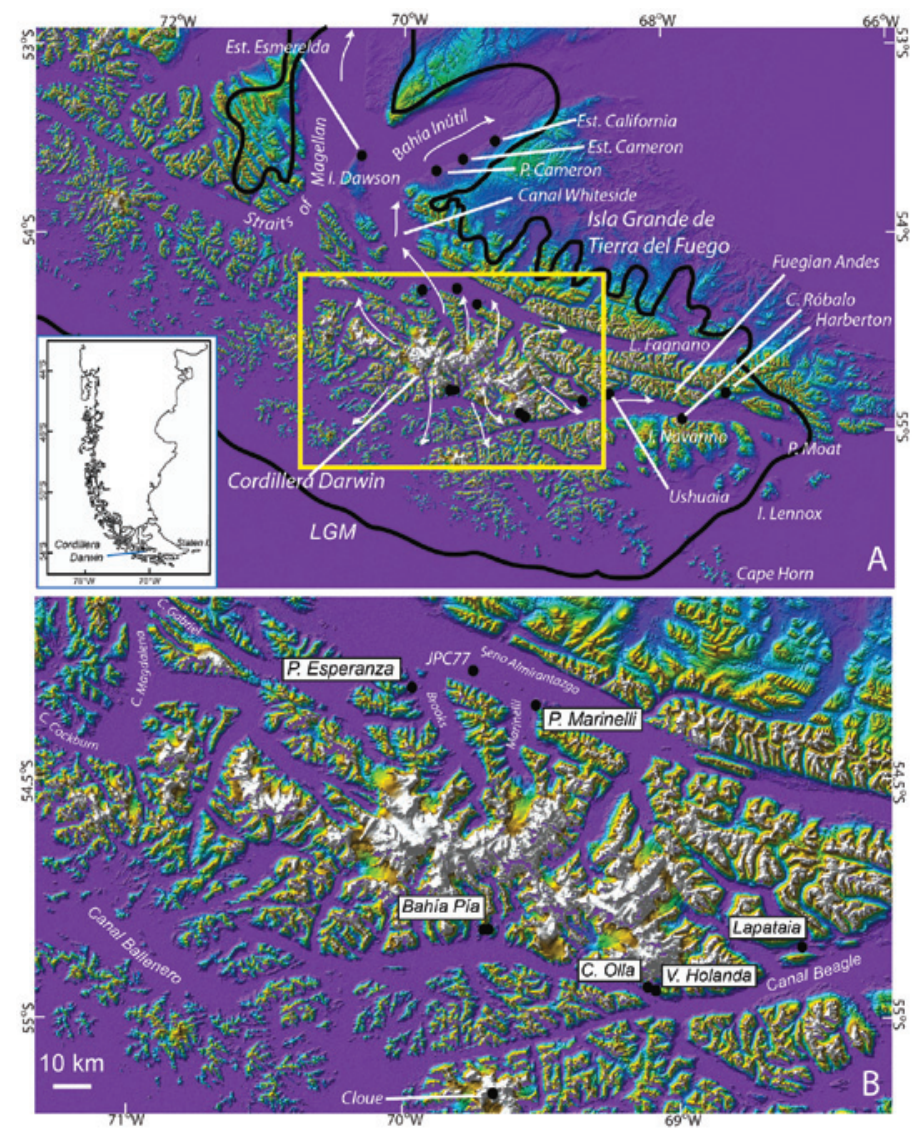

Figure 1. Index map of Cordillera Darwin, showing locations mentioned in the text. Base image is a digital elevation model constructed from Shuttle Radar Topography Mission (SRTM) data. Modified after Hall et al. (2013). 

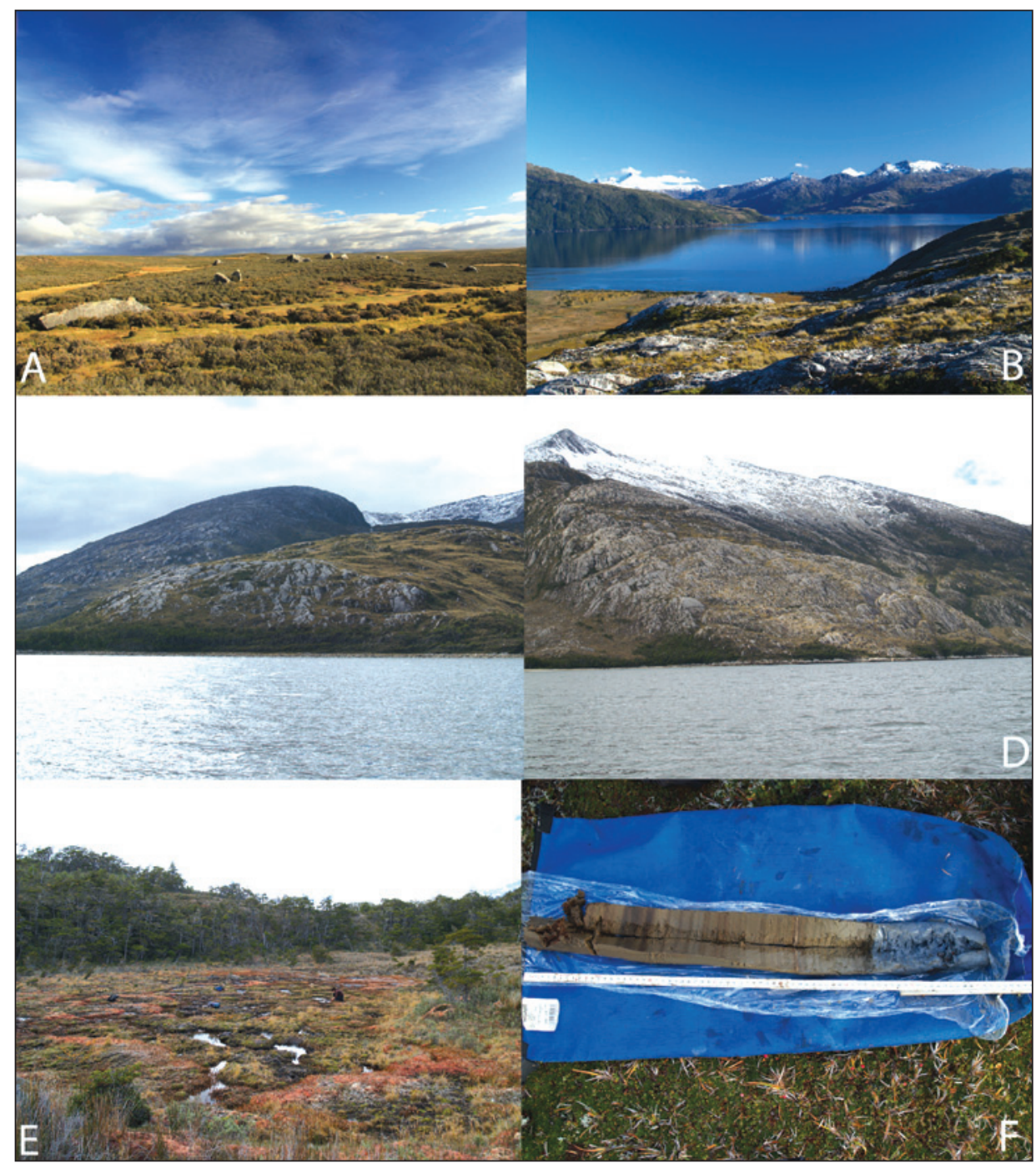

Figure 2. Glacial features in Tierra del Fuego. A. "Darwin's Boulders" along the right-lateral moraines adjacent to Bahía Inútil; B. Topography adjacent to Canal Beagle, near Bahía Pía; $C$. and D. Areally scoured terrain in the interior of Cordillera Darwin along Canal Beagle; E. Punta Marinelli bog; F. Lower meter of the MARPT-07-02 core, showing organic sediment (left) overlying blue-gray glacial lacustrine clay (right). Scale marks are in centimeters.

the eastern end of the bay (Caldenius, 1932; Meglioli, 1992; Clapperton et al., 1995; Bentley et al., 2005; McCulloch et al., 2005a, 2005b; Evenson et al., 2009; Darvill et $a l ., 2014)$. The moraines can be traced southeastward across Isla Grande, where they are thought to correlate with those enclosing the eastern end of Lago Fagnano (Coronato et $a l ., 2009)$. One distinguishing feature of the right lateral moraines at Bahía Inútil is the presence of a train of large boulders of Beagle granite (Fig. 2A). Known as Darwin's 
Boulders (Evenson et al., 2009), these erratics mark a former ice flowline from central Cordillera Darwin that, based on lithology, must have originated at the head of Marinelli and/or Brooks fjords (Fig. 1B).

The age of many of the Bahía Inútil moraines is uncertain. The traditional paradigm is that the inner belts of moraines closest to the bay $(\mathrm{B}, \mathrm{C}$, and $\mathrm{D}$ of Bentley et al., 2005) date to the LGM and that the outer moraines (A and older), particularly those along the Atlantic coast, relate to much older glaciations (Meglioli, 1992; McCulloch et al., 2005; Evenson et al., 2009). In this context, boulders in the older moraine belts that yield what seem to be anomalously "young" ages have been interpreted as having loss of cosmogenic nuclides from significant erosion (e.g., Kaplan et al., 2007; Evenson et al., 2009). However, Darvill et al. (2015), noting that Darwin's Boulders all appear to be from a single flowline and show similar degrees of weathering, opened the possibility that many of the outer moraines are younger than previously thought and may be from the last glaciation.

The LGM moraine belt trends southeastward from Bahía Inútil to Lago Fagnano, where it extends around the eastern end of the lake. The Lago Fagnano ice lobe was fed by an outlet glacier that streamed southeastward through Seno Almirantazgo, as well as by input from local alpine glaciers (Coronato et al., 2009). Radiocarbon ages of peat layers within deltaic deposits below till suggest that ice advance to the LGM position occurred after $36 \mathrm{ka}$ (Bujalesky et al., 1997; Coronato et al., 2009), although it is uncertain if the radiocarbon ages are truly finite.

On the south side of the former Darwin ice field, the only flow line known with some confidence is one that extended eastward along Canal Beagle, terminating at Punta Moat, where it formed moraines near the junction with the Atlantic Ocean (Rabassa et $a l ., 1990,2000)$. The LGM ice position along the southern and western margins of the icefield remains uncertain, as there are no documented terminal moraines and the ice likely terminated offshore. Caldenius (1932) placed the ice margin near the shelf edge, whereas Coronato et al. (1999) drew it closer to the present-day coast and showed extensive subaerial outwash plains on what is now the continental shelf.

The timing of the youngest LGM moraine -the age of which affords a close maximum limit on the timing of deglaciation- is known only near Bahía Inútil. Here, ${ }^{10} \mathrm{Be}$ cosmogenic surface-exposure ages of boulders on moraine crests suggest an age of $\sim 18.4 \pm 1.7 \mathrm{ka}$ for the innermost moraines along the south shore of the bay (errorweighted mean of five ages published in McCulloch et al. (2005b) and Kaplan et al. (2008a), recalculated in Kaplan et al. (2011); see Fig. 3A and Table 2).

\section{Timing of Recession}

Information on the timing of ice recession comes primarily from radiocarbon dates of the lowest organic materials found in bogs that lie proximal to the LGM moraine belt. Such dates afford minimum-limiting radiocarbon ages for deglaciation. In humid areas, such as Cordillera Darwin, re-vegetation following deglaciation appears to have occurred quickly. Observation today suggests a lag time there of less than a decade for vegetation growth 
following ice retreat in Cordillera Darwin (C. Porter, unpublished data). The delay in revegetation may be more substantial in drier areas of Isla Grande (Coronato et al., 1999).

Radiocarbon dates of basal organic materials in bogs adjacent to Bahía Inútil and on northern Isla Dawson afford minimum ages for initial deglaciation from the D moraines (Table 1). McCulloch et al. (2005b) obtained ages as old as $\sim 17 \mathrm{ka}$ from bogs inboard of the D moraines on the south shore of the bay at Estancias Cameron and California (Figs. 1A, 3A). The northern tip of Isla Dawson may have been deglaciated by about the same time (Clapperton et al., 1995; McCulloch and Bentley, 1998; McCulloch et al., 2005b).

More recently, Hall et al. (2013) cored bogs in the interior of Cordillera Darwin along the same ice flow lines that fed the Bahía Inútil lobe. Ice emanating from Brooks fjord flowed north through Canal Whiteside to feed the Bahía Inútil lobe at the LGM. The flow direction of ice discharging from Marinelli fjord is less clear. Although it is likely that ice from this fjord also augmented the Bahía Inútil lobe, the possibility cannot be discounted that it may have contributed to ice that ultimately fed the Lago Fagnano lobe. In either case, dates of basal organic materials in bogs from these sites afford minimum ages for the retreat of the former Darwin icefield back into the heart of the mountains. At Brooks fjord, a radiocarbon date of organic material within a core at Punta Esperanza yielded a minimum age for deglaciation of $\sim 16.1 \mathrm{ka}$ (Hall et al., 2013; Table 1; Fig. 3B). This date is not thought to afford a close-limiting age, because the core did not penetrate to the glacial clay, and thus it is not known if the lowest organic materials were sampled. To the east at the mouth of Marinelli fjord, six samples of plant remains within four centimeters of the top of the glacial lacustrine clay yielded a weighted mean of $16.3 \pm 0.5 \mathrm{ka}$ (Hall et al., 2013; Fig. 2F, Table 1). The location of this bog indicates that ice must have retreated to within seven kilometers of the position it occupied in the 20th century by that time. Additional confirmation for the basal ages in both the Marinelli and Brooks bogs comes from the presence of the Reclus tephra ( 15 ka; Stern, 2008) at higher levels in the cores at both sites (Hall et al., 2013). Moreover, a core from the adjacent sound produced an age of $\sim 15.7 \mathrm{ka}$ for the lowest recovered marine carbonate, consistent with deglaciation prior to that time (Boyd et al., 2008). Thus, it seems likely that the Darwin icefield had receded back into the mountains on the north side of the Cordillera by at least $\sim 16.3 \mathrm{ka}$.

There are also ages for basal organic materials in several bogs on the south side of Cordillera Darwin. Along eastern Canal Beagle $~ 50 \mathrm{~km}$ inboard of the Moat moraines, Heusser (1989a) obtained an age of $\sim 17.8$ ka for the lowest organic materials within a bog at Harberton. This age affords evidence that deglaciation from the LGM position was already underway at that time. Other dates from bogs located along eastern Canal Beagle have been interpreted as showing a pattern of gradual ice retreat towards the center of Cordillera Darwin (Fig. 3A, B; Heusser, 1998; Rabassa et al., 2000). Organic material in a bog at Caleta Róbalo on Isla Navarino produced an age of $\sim 15.1 \mathrm{ka}$. Another bog near Ushuaia gave an age of $\sim 14.5 \mathrm{ka}$, whereas one farther west at Lapataia yielded a date of $\sim 11.8 \mathrm{ka}$. However, recent data from the center of Cordillera Darwin conflicts with this pattern of slow retreat. From dates of bogs near Bahía Pía, Hall et al. (2013) concluded that ice had retreated far into the interior of Cordillera Darwin prior to $14.5 \mathrm{ka}$ (Table 1; Fig. 3B). Support for this minimum-limiting age comes from a core near Ventisquero 
Holanda, only $800 \mathrm{~m}$ from the late Holocene moraine complex. Plant remains overlying basal gravel there produced an age of $14.8 \mathrm{ka}$. This date is not thought to be a closeminimum age, because it came from hillside peat rather than from a bog. However, the date shows that ice retreat had progressed to nearly modern positions by at least $\sim 15 \mathrm{ka}$.

A cosmogenic surface exposure age dataset from the Fuegian Andes along eastern Canal Beagle further constrains the timing of ice retreat in Tierra del Fuego. Although focused primarily on the Holocene record, Menounos et al. (2013) obtained two dates of bedrock just distal to the Late-Glacial (Antarctic Cold Reversal) moraine. Similar to the date from Harberton, these ages indicate that alpine ice in the eastern part of Tierra del Fuego had already begun to retreat by $\sim 17.8 \mathrm{ka}$ and had receded to at least its LateGlacial position by $\sim 16.7 \mathrm{ka}$ (Table 2; Fig. 3A).
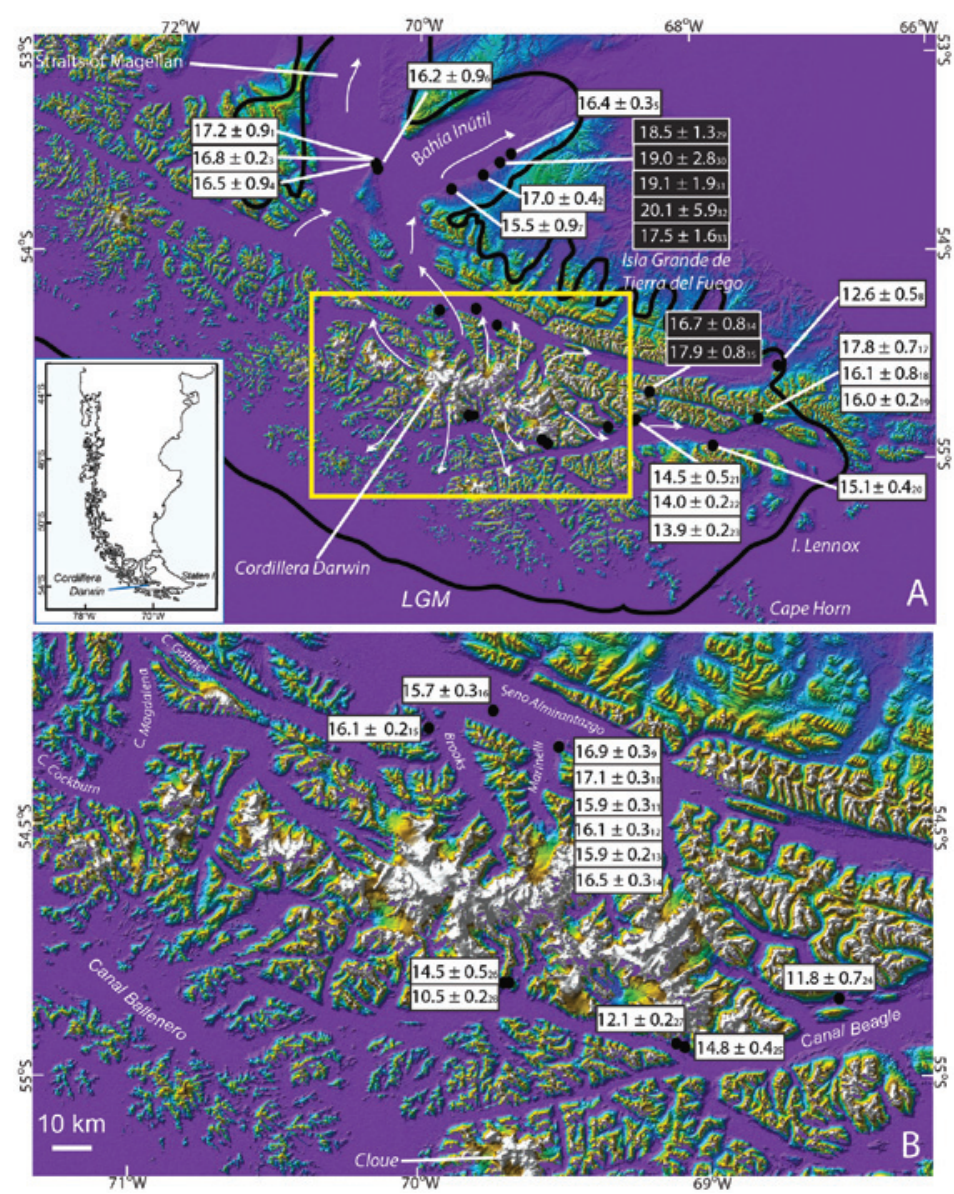

Figure 3. Chronologic constraints on the timing of ice recession in Tierra del Fuego during the last termination. Dates on black background are ${ }^{10}$ Be surface exposure ages and afford actual ages of moraines and erratics that record former ice position (Table 2). Dates on white background are minimum-limiting radiocarbon ages for deglaciation (Table 1). 
Available evidence from Cordillera Darwin suggests only modest ice advance during the subsequent Antarctic Cold Reversal. Although early reports suggested a major ACR advance to the vicinity of Isla Dawson on the north side of Cordillera Darwin (McCulloch et al., 2005a), sediment cores from Puntas Esperanza and Marinelli are at odds with that interpretation, as they lack any evidence for a readvance following initial deglaciation. The Punta Esperanza bog core, in particular, would have been covered by any ice that advanced north from Cordillera Darwin through Canal Whiteside to Isla Dawson. Therefore, we conclude that the deposits attributed to the ACR must date to an earlier time period. The only confirmed ACR-age moraines are from cirque glaciers in the Fuegian Andes, where the ice margins lay only $0.85-2.5 \mathrm{~km}$ beyond their present positions (Menounos et al., 2013). Moraines similar in appearance and position relative to the modern glaciers occur in central Cordillera Darwin; work is under way to determine their age (Hall et al., in prep.).

In summary, available data on both sides of Cordillera Darwin, as well as in the Fuegian Andes, suggest rapid ice recession shortly after the start of Termination I ( $\sim 18 \mathrm{ka})$, with retreat into the interior fjords no later than $\sim 16.5 \mathrm{ka}$ on the north side and at $>\sim 14.8$ $\mathrm{ka}$ on the south flank of the mountain range. The icefield at that time appear to have retreated at least to its Late-Glacial position, if not behind the fronts of present-day glaciers. To put this recession in context, such a retreat resulted in a loss of $>85 \%$ of the Brooks flowline in $<\sim 2000$ years. Such a rapid recession is remarkably similar to that in earlier modelling studies by Hulton et al. (2002), who suggested that $80 \%$ of the icefield may have disappeared within 2000 years of the start of Termination I, based on application of a rapid $6^{\circ} \mathrm{C}$ temperature warming in the model.

\section{Mechanisms}

What caused rapid recession of the Darwin icefield shortly after $18 \mathrm{ka}$ ? Although several factors can cause glaciers to retreat (rising air temperatures, decreased precipitation, rapid calving in a marine environment), available information favors a significant air-temperature increase, which caused a rapid rise in regional equilibriumline altitudes (ELA). Numerous studies have shown the temperature-sensitivity of mountain glaciers (i.e., Oerlemans, 2005; Zemp et al., 2015), but the most pertinent here is an in-depth latitudinal study of Andean glaciers, including those in Cordillera Darwin. Using a surface energy-balance model, Sagredo et al. (2014) found that ELA is relatively insensitive to precipitation changes in humid, cloudy environments, such as Cordillera Darwin, because of the link between surface energy balance and atmospheric emissivity. They further calculated that a precipitation increase of $\sim 75 \%$ (in an area already very wet) would be required to offset a $1^{\circ} \mathrm{C}$ temperature rise in Cordillera Darwin (Sagredo et al., 2014). We thus feel comfortable with concluding that rapid ice recession in Cordillera Darwin during Termination I was due primarily to rising air temperatures and not to precipitation deficits. This interpretation is consistent not only with new Antarctic ice-core temperature records (e.g., WAIS Divide, Buizert et al., 2015; Fig. 4), but also with the marine record offshore of southwestern Chile, which shows a warming ocean at the same time (Lamy et al., 2004; Kaiser et al., 2005; 


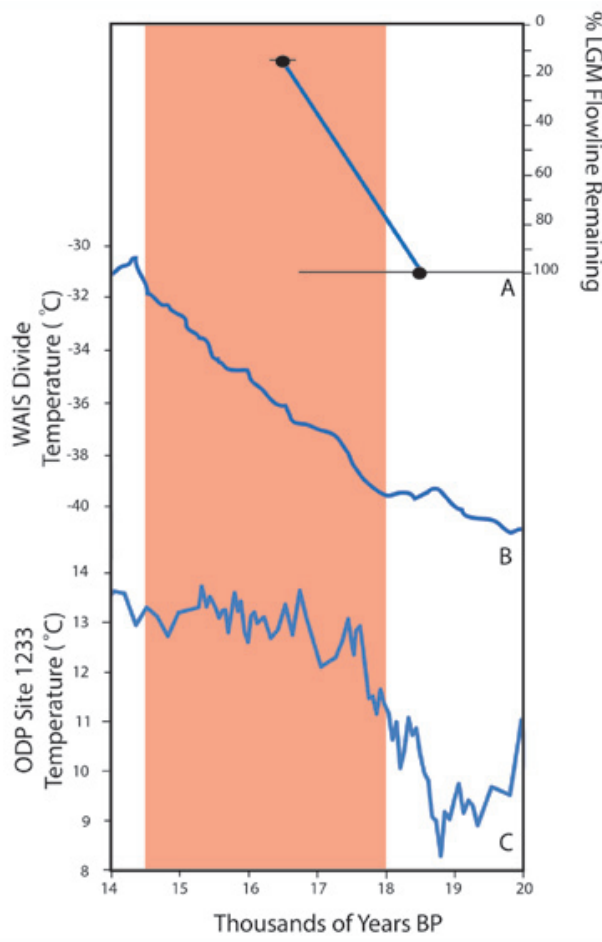

Figure 4. Retreat of the Cordillera Darwin icefield compared to marine sea-surface and atmospheric temperatures during the termination of the last ice age. A) Percent of the LGM flowline remaining, based on distance from the head of Brooks fjord to the Bahía Inútil " $D$ " moraines. B) Air temperatures from the WAIS Divide ice core in West Antarctica, based on $\delta D$ measurements calibrated against borehole temperatures (Buizert et al., 2015). C) Alkenonebased sea-surface temperatures for waters off Chile at site ODP 1233 (41 ${ }^{\circ} \mathrm{S}$; Lamy et al., 2007). Red bar shows approximate timing of $H S-1$ in the North Atlantic region.

Caniupán et al., 2011; Saavedra-Pellitero et al., 2011). Although the warm marine water did not directly impact much of the Cordillera Darwin icefield through melting at the grounding line during initial deglaciation [the sea did not flood the Straits of Magellan and Canal Beagle until later (e.g., Bujalesky et al., 1997), and much of the glaciated continental shelf was above sea level], ocean and atmospheric temperatures are commonly linked in this region (e.g., McKinnon et al., 2013). Thus, the rapid recession of the Cordillera Darwin icefield at $\sim 18$ ka likely was a symptom of rapidly warming climate during Termination I.

\section{Summary}

The major pulse of deglaciation of Tierra del Fuego commenced at $\sim 18$ ka, with recession of the Cordillera Darwin icefield documented from both Bahía Inútil in the north and Canal Beagle in the south. Alpine glaciers in the Fuegian Andes also likely retreated at that time. Radiocarbon ages from the interior regions of Cordillera Darwin 
suggest ice in at least some locations had retreated close to its present-day limit as early as $\sim 16.5 \mathrm{ka}$. The most likely cause for such rapid ice retreat was rising atmospheric temperatures at the start of Termination I.

\section{Acknowledgements}

We are indebted to the late Charlie Porter for his insights into the fjords of Cordillera Darwin, for his knowledge of local weather conditions derived from a network of automated weather stations, and for the use of his boat, Ocean Tramp. We also acknowledge funding for our field work in Tierra del Fuego from the US National Science Foundation and from the Comer Family Foundation. We would like to thank the reviewers and editors for very helpful reviews.

\section{References}

Anderson, R.F., Ali, S., Bradtmiller, L., Nielsen, S.H.H., Fleisher, M.Q., Anderson, B.E., Burckle, L.H. 2009. Wind-driven upwelling in the Southern Ocean and the deglacial rise in atmospheric $\mathrm{CO}_{2}$. Science 323 (5920), 1443-1448. http://doi.org/10.1126/science.1167441.

Balco, G., Stone, J.O., Lifton, N.A., Dunai, T.J. 2008. A complete and easily accessible means of calculating surface exposure ages or erosion rates from ${ }^{10} \mathrm{Be}$ and ${ }^{26} \mathrm{Al}$ measurements. Quaternary Geochronology 3 (3), 174-195. http://doi.org/10.1016/j.quageo.2007.12.001.

Bentley, M.J., Sugden, D., Hulton, N.R.J., McCulloch, R.D. 2005. The landforms and pattern of deglaciation in the Strait of Magellan and Bahía Inútil, southernmost South America. Geografiska Annaler 87A (2), 313-333. http://doi.org/10.1111/j.0435-3676.2005.00261.x.

Björck, S., Rundgren, M., Ljung, K., Unkel, I., Wallin, Å. 2012. Multi-proxy analyses of a peat bog on Isla de los Estados, easternmost Tierra del Fuego: a unique record of the variable Southern Hemisphere westerlies since the last deglaciation. Quaternary Science Reviews 42, 1-14. http://doi.org/10.1016/j.quascirev.2012.03.015.

Boyd, B.L., Anderson, J.B., Wellner, J.S., Fernandez, R.A. 2008. The sedimentary record of glacial retreat, Marinelli Fjord, Patagonia: Regional correlations and climate ties. Marine Geology 255 (3-4), 165-178. http://doi.org/10.1016/j.margeo.2008.09.001.

Broecker, W. 1998. Paleocean circulation during the last deglaciation: A bipolar seesaw? Paleoceanography 13 (2), 119-121. http://doi.org/10.1029/97PA03707.

Buizert, C., Cuffey, K.M., Severinghaus, J.P., Baggenstos, D., Fudge, T.J., Steig, E.J., Markle, B.R., Winstrup, M., Rhodes, R.H., Brook, E.J., Sowers, T.A., Clow, G.D., Cheng, H., Edwards, R.L., Sigl, M., McConnell, J.R., Taylor, K.C. 2015. The WAIS Divide deep ice core WD2014 chronology - Part 1: Methane synchronization (68-31 ka BP) and the gas age-ice age difference. Climate of the Past 11, 153-173. http://doi.org/10.5194/cp-11-153-2015.

Bujalesky, G. 2011. The flood of the Beagle Valley (11,000 yr BP), Tierra del Fuego. Anales Instituto Patagonia 39 (1), 5-21. http://doi.org/10.4067/S0718-686X2011000100001.

Bujalesky, G., Heusser, C., Coronato, A., Roig, C., Rabassa, J. 1997. Pleistocene glaciolacustrine sedimentation at Lago Fagnano, Andes of Tierra del Fuego, southernmost South America. Quaternary Science Reviews 16, 767-778. http://doi.org/10.1016/S0277-3791(97)00018-8.

Caldenius, C.C. 1932. Las glaciaciones Cuaternarias en la Patagonia y Tierra del Fuego. Geografiska Annaler 14, 1-164 (English summary, p. 144-157).

Caniupán, M., Lamy, F., Lange, C.B., Kaiser, J., Arz, H., Killian, R., Baeza, O. 2011. Millennialscale sea-surface temperature and Patagonian Ice Sheet changes off southernmost Chile $\left(53^{\circ} \mathrm{S}\right)$ over the past 60 kyr. Paleoceanography 26, PA3221. http://doi.org/10.1029/2010PA002049. 
Clapperton, C., Sugden, D., Kaufman, D.S., McCulloch, R.D. 1995. The last glaciation in central Magellan Strait, southernmost Chile. Quaternary Research 44 (2), 133-148. http://doi. org/10.1016/qres.1995.1058.

Coronato, A., Salemme, M., Rabassa, J. 1999. Palaeoenvironmental conditions during the early peopling of Southernmost South America (Late Glacial-Early Holocene, 14-8 ka B.P.). Quaternary International 53/54, 77-92. http://doi.org/10.1016/S1040-6182(98)00009-3.

Coronato, A., Seppälä, M., Ponce, J.F., Rabassa, J. 2009. Glacial geomorphology of the Pleistocene Lake Fagnano ice lobe, Tierra del Fuego, southern South America. Geomorphology 112 (12), 67-81. http://doi.org/10.1016/j.geomorph.2009.05.005.

Darvill, C.M., Stokes, C.R., Bentley, M.J., Lovell, H. 2014. A glacial geomorphological map of the southernmost ice lobes of Patagonia: The Bahía Inútil - San Sebastían, Magellan, Otway, Skyring, and Río Gallegos lobes. Journal of Maps 10 (3), 500-520. http://doi. org/10.1080/17445647.2014.890134.

Darvill, C.M., Bentley, M.J., Stokes, C.R. 2015. Geomorphology and weathering characteristics of erratic boulder trains on Tierra del Fuego, southernmost South America: Implications for dating of glacial deposits. Geomorphology 228, 382-397. http://doi.org/10.1016/j. geomorph.2014.09.017.

Denton, G., Anderson, R.F., Toggweiler, J.R., Edwards, R.L., Schaefer, J., Putnam, A. 2010. The last glacial termination. Science 326 (5986), 1652-1656. http://doi.org/10.1126/science.1184119.

Denton, G., Heusser, C., Lowell, T., Moreno, P., Andersen, B.G., Heusser, L.E., Schlüchter, C., Marchant, D. 1999a. Interhemispheric linkage of paleoclimate during the last glaciation. Geografiska Annaler 81A (2), 107-153. http://doi.org/10.1111/1468-0459.00055.

Denton, G., Lowell, T., Heusser, C., Schlüchter, C., Andersen, B.G., Heusser, L., Moreno, P., Marchant, D. 1999b. Geomorphology, stratigraphy, and radiocarbon chronology of Llanquihue drift in the area of the southern Lake District, Seno Reloncaví, and Isla Grande de Chiloé, Chile. Geografiska Annaler 81A (2), 167-229. http://doi.org/10.1111/14680459.00057.

Evenson, E., Burkhart, P., Gosse, J., Baker, G., Jackofsky, D., Meglioli, A., Dalziel, I., Kraus, S., Alley, R., Berti, C. 2009. Enigmatic boulder trains, supraglacial rock avalanches, and the origin of "Darwin's boulders," Tierra del Fuego. GSA Today 19, 4-10. http://doi.org/10.1130/ GSATG72A.1.

Fontana, S.L., Bennett, K.D. 2012. Postglacial vegetation dynamics of western Tierra del Fuego. The Holocene 22, 1337-1350. http://doi.org/10.1177/0959683612444144.

Hall, B.L., Porter, C.T., Denton, G.H., Lowell, T.V., Bromley, G.R.M. 2013. Extensive recession of Cordillera Darwin glaciers in southernmost South America during Heinrich Stadial 1. Quaternary Science Reviews 62, 49-55. http://doi.org/10.1016/j.quascirev.2012.11.026.

Heusser, C. 1989a. Climate and chronology of Antarctica and adjacent South America over the past 30,000 yr. Palaeogeography, Palaeoclimatology, Palaeoecology 76 (1-2), 31-37. http:// doi.org/10.1016/0031-0182(89)90101-6.

Heusser, C. 1989b. Late Quaternary vegetation and climate of southern Tierra del Fuego. Quaternary Research 31, 396-406. http://doi.org/10.1016/0033-5894(89)90047-1.

Heusser, C. 1998. Deglacial palaeoclimate of the American sector of the Southern Ocean. Late Glacial-Holocene records from the latitude of Canal Beagle $\left(55^{\circ} \mathrm{S}\right)$, Argentine Tierra del Fuego. Palaeogeography, Palaeoclimatology, Palaeoecology 141 (3-4), 277-301. http://doi. org/10.1016/S0031-0182(98)00053-4.

Heusser, C. 2003. Ice Age Southern Andes: A chronicle of palaeoecological events. Volume 3.Elsevier, Netherlands.

Holmlund, P., Fuenzalida, H. 1995. Anomalous glacier responses to 20th century climatic changes in Darwin Cordillera, southern Chile. Journal of Glaciology 41 (139), 465-473. http://doi.or g/10.3198/1995JoG41-139-465-473. 
Hulton, N.R.J., Purves, R.S., McCulloch, R.D., Sugden, D.E., Bentley, M.J. 2002. The Last Glacial Maximum and deglaciation in southern South America. Quaternary Science Reviews 21: 233-241. http://doi.org/10.1016/S0277-3791(01)00103-2.

Huybers, P., Denton, G. 2008. Antarctic temperature at orbital timescales controlled by local summer duration. Nature Geoscience 1, 787-792. http://doi.org/10.1038/ngeo311.

Kaiser, J., Lamy, F., Hebbeln, D. 2005. A 70-kyr sea surface temperature record off southern Chile (Ocean Drilling Program Site 1233). Paleoceanography 20, PA4009. http://doi. org/10.1029/2005PA001146.

Kaplan, M.R., Coronato, A., Hulton, N.R.J., Rabassa, J.O., Kubik, P.W., Freeman, S.P.H.T. 2007. Cosmogenic nuclide measurements in southernmost South America and implications for landscape change. Geomorphology 87, 284-301. http://doi.org/10.1016/j. geomorph.2006.10.005

Kaplan, M., Fogwill, C., Sugden, D., Hulton, N.R.J., Kubik, P., Freeman, S.P.H.T. 2008a. Southern Patagonian glacial chronology for the last glacial period and implications for Southern Ocean climate. Quaternary Science Reviews 27 (3-4), 284-294. http://doi.org/10.1016/j. quascirev.2007.09.013.

Kaplan, M., Moreno, P.I., Rojas, M. 2008b. Glacial dynamics in southernmost South America during Marine Isotope Stage 5e to the Younger Dryas chron: a brief review with a focus on cosmogenic nuclide measurements. Journal of Quaternary Science 23 (6-7), 649-658. http:// doi.org/10.1002/jqs.1209.

Kaplan, M., Strelin, J., Schaefer, J., Denton, G., Finkel, R., Schwartz, R., Putnam, M., Vandergoes, M., Goehring, B., Travis, S. 2011. In-situ cosmogenic ${ }^{10}$ Be production rate at Lago Argentino, Patagonia: Implications for late-glacial climate chronology. Earth and Planetary Science Letters 309 (1-2), 21-32. http://doi.org/10.1016/j.eps1.2011.06.018.

Kohfeld, K.E., Graham, R.M., de Boer, A.M., Sime, L.C., Wolff, E.W.,Le Quére, C., Bopp, L. 2013. Southern Hemisphere westerly wind changes during the Last Glacial Maximum: paleo-data synthesis. Quaternary Science Reviews 68, 76-95. http://doi.org/10.1016/j.quascirev.2013.01.017.

Lal, D. 1991. Cosmic ray labeling of erosion surfaces: in situ nuclide production rates and erosion models. Earth and Planetary Science Letters 104 (2-4), 424-439. http://doi.org/10.1016/0012821X(91)90220-C.

Lamy, F., Kaiser, J., Ninnemann, U., Hebbeln, D., Arz, H., Stoner, J. 2004. Antarctic timing of surface water changes off Chile and Patagonian Ice Sheet response. Science 304 (5679), 1959-1962. http://doi.org/10.1126/science.1097863.

Lamy, F., Kaiser, J., Arz, H.W., Hebbeln, D., Ninnemann, U., Timm, O., Timmermann, A., Toggweiler, R. 2007. Modulation of the bipolar seesaw in the southeast Pacific during Termination I. Earth and Planetary Science Letters 259 (3-4), 400-413. http://doi. org/10.1016/j.epsl.2007.04.040.

Lliljequist, G. 1970. Klimatologie: Stockholm, Generalstabens Litografiska Anstalt.

Markgraf, V., Huber, U. 2010. Late and postglacial vegetation and fire history in southern Patagonia and Tierra del Fuego. Palaeogeography, Palaeoclimatology, Palaeoecology 297, 351-366. http://doi.org/10.1016/j.palaeo.2010.08.013.

McCulloch, R.D., Bentley, M.J. 1998. Late-glacial ice advances in the Strait of Magellan, southern Chile. Quaternary Science Reviews 17, 775-787. http://doi.org/10.1016/S02773791(97)00074-7.

McCulloch, R.D., Bentley, M.J., Tipping, R.M., Clapperton, C. 2005a. Evidence for late-glacial ice dammed lakes in the central Strait of Magellan and Bahía Inútil, southernmost South America. Geografiska Annaler 87A (2), 335-362. http://doi.org/j.0435-3676.2005.00262.x.

McCulloch, R.D., Fogwill, C., Sugden, D., Bentley, M.J., Kubik, P. 2005b. Chronology of the last glaciation in the central Strait of Magellan and Bahía Inútil, southernmost South America. Geografiska Annaler 87A (2), 289-312. http://doi.org/j.0435-3676.2005.00260.x. 
McKinnon, K.A., Stine, A., Huybers, P. 2013. The spatial structure of the annual cycle in surface temperature: amplitude, phase, and Lagrangian history. Journal of Climate 26, 7852-7862. http://doi.org/10.1175/JCLI-D-13-00021.1.

McManus, J., Francois, R., Gherardi, J.M., Keigwin, L., Brown-Leger, S. 2004 . Collapse and rapid resumption of Atlantic meridional circulation linked to deglacial climate changes. Nature 428, 834-837. http://doi.org/10.1038/nature02494.

Meglioli,A. 1992. Glacial geology of southernmost Patagonia, the Strait of Magellan and northern Tierra del Fuego. Ph.D. Dissertation, Lehigh University, Bethlehem, PA.

Menounos, B., Clague, J.J., Osborn, G., Thompson Davis, P., Ponce, F., Goehring, B., Maurer, M., Rabassa, R., Coronato, A., Marr, R. 2013. Latest Pleistocene and Holocene glacier fluctuations in southernmost Tierra del Fuego, Argentina. Quaternary Science Reviews 77, 70-79. http://doi.org/10.1016/j.quascirev.2013.07.008.

Mix, A.C, Bard, E., Schneider, R. 2001. Environmental processes of the last ice age: land, oceans, glaciers (EPILOG). Quaternary Science Reviews 20, 627-657. http://doi.org/10.1016/S02773791(00)00145-1.

Möller, P., Hjort, C., Björck, S., Rabassa, J., Ponce, J.F. 2010. Late Quaternary glaciation history of Isla de los Estados, southeasternmost South America. Quaternary Research 73, 521-534. http://doi.org/10.1016/j.yqres.2010.02.004.

Moreno, P.I., Kaplan, M., François, J.P., Villa-Martínez, R.P., Moy, C.M., Stern, C., Kubik, P. 2009. Renewed glacial activity during the Antarctic Cold Reversal and persistence of cold conditions until $11.5 \mathrm{ka}$ in SW Patagonia. Geology 37 (4), 375-378. http://doi.org/10.1130/ G25399A.1.

Moreno,P.I., Villa-Martínez, R.,Cárdenas, M.L., Sagredo,E.A. 2012. Deglacial changes of the southern margin of the southern westerly winds revealed by terrestrial records from SW Patagonia $\left(52^{\circ} \mathrm{S}\right)$. Quaternary Science Reviews 41, 1-21. http://doi.org/10.1016/j.quascirev.2012.02.002.

Oerlemans, J. 2005. Extracting a Climate Signal from 169 Glacier Records. Science 308 (5722), 675-677. http://doi.org/10.1126/science.1107046.

Rabassa, J. 2008. Late Cenozoic glaciations in Patagonia and Tierra del Fuego. In: J. Rabassa (Ed.), The Late Cenozoic of Patagonia and Tierra del Fuego, Developments in Quaternary Sciences 11, 151-204. http://doi.org/10.1016/S1571-0866(07)10008-7.

Rabassa, J., Coronato, A., Bujalesky, C., Roig, F., Salemme, M., Meglioli, A., Heusser, C., Gordillo, S., Borromei, A., Quatrocchio, M.J. 2000. Quaternary of Tierra del Fuego, southernmost South America: an updated review. Quaternary International 68-71, 217-240. http://doi. org/10.1016/S1040-6182(00)00046-X.

Rabassa, J., Coronato, A., Martínez, O. 2011. Late Cenozoic glaciations in Patagonia and Tierra del Fuego: an updated review. Biological Journal of the Linnean Society 103, 316-335. http:// doi.org/10.1111/j.1095-8312.2011.01681.x.

Rabassa, J., Heusser, C., Rutter, N. 1990. Late-glacial and Holocene of Argentine Tierra del Fuego. Quaternary of South America and Subantarctic Islands 7, 327-351.

Rabassa, J., Heusser, C., Rutter, N. 1989. Late Glacial and Holocene of Argentina, Tierra del Fuego. Quaternary of South America \& Antarctic Peninsula, 7, 327-351, A.A. Balkema Publishers, Rotterdam.

Reimer, P., Bard, E., Bayliss, A., Beck, J.W., Blackwell, P.G., Bronk Ramsey, C., Buck, C.E., Cheng, H., Edwards, R.L., Friedrich, M., Grootes, P.M., Guilderson, T.P., Haflidason, H., Hajdas, I., Hatté, C., Heaton, T.J., Hoffmann, D.L., Hogg, A., Hughen, K.A., Kaiser, K.F., Kromer, B., Manning, S.W., Niu, M., Reimer, R.W., Richards, D.A., Scott, E.M., Southon, J.R., Staff, R.A., Turney, C.S.M., van der Plicht, J. 2013. IntCal13 and Marine13 Radiocarbon age calibration curves 0-50,000 years cal BP. Radiocarbon 55 (4), 1869-1887. http://doi. org/10.2458/azu_js_rc.55.16947. 
Saavedra-Pellitero, M., Flores, J.A., Lamy, F., Sierro, F.J., Cortina, A. 2011. Coccolithophore estimates of paleotemperature and paleoproductivity changes in the southeast Pacific over the past $27 \mathrm{kyr}$. Paleoceanography 26 (1). http://doi.org/10.1029/2009PA001824.

Sagredo, E.A., Rupper, S., Lowell, T.V. 2014. Sensitivities of the equilibrium line altitude to temperature and precipitation changes along the Andes. Quaternary Research 81 (2), 355366. http://doi.org/10.1016/j.yqres.2014.01.008.

Stern, C.R. 2008. Holocene tephrochronology record of large explosive eruptions in the southernmost Patagonian Andes. Bulletin of Volcanology 70 (4), 435-454. http://doi. org/10.1007/s00445-007-0148-z.

Stone, J.O. 2000. Air pressure and cosmogenic isotope production. Journal of Geophysical Research 105 (B10), 23753-23759. http://doi.org/10.1029/2000JB900181.

Strelin, J., Denton, G., Vandergoes, M., Ninnemann, U., Putnam, A. 2011. Radiocarbon chronology of the late-glacial Puerto Bandera moraines, Southern Patagonian Icefield, Argentina. Quaternary Science Reviews 30 (19-20), 2551-2569. http://doi.org/10.1016/j. quascirev.2011.05.004.

Toggweiler, J.R., Russell, J.L., Carson, S.R. 2006. Mid-latitude westerlies, atmospheric $\mathrm{CO}_{2}$, and climate change during the ice ages. Paleoceanography 21, PA2005. http://doi. org/10.1029/2005PA001154.

Tuhkanen, S. 1992. The climate of Tierra del Fuego from a vegetation geographical point of view and its ecoclimatic counterparts elsewhere. Acta Botánica Fennica 125, 4-17.

Unkel, I., Björck, S., Wohlfarth, B. 2008. Deglacial environmental changes on Isla de los Estados $\left(54.5^{\circ} \mathrm{S}\right)$, southeastern Tierra del Fuego. Quaternary Science Reviews 27 (15-16), 15411554. http://doi.org/10.1016/j.quascirev.2008.05.004.

Vanneste, H., De Vleeschouwer, F., Martínez-Cortizas, A., von Scheffer, C., Piotrowska, N., Coronato, A., Le Roux, G. 2015. Late-glacial elevated dust deposition linked to westerly wind shifts in southern South America. Nature Scientific Reports 5, 11670. http://doi. org/10.1038/srep11670.

Zemp, M., Frey, H., Gärtner-Roer, I., Nussbaumer, S.U., Hoelzle, M., Paul, F., Haeberli, W., Denzinger, F., Ahlstrom, A.P., Anderson, B., Balracharya, S., Baroni, C., Braun, L.N., Cáceres, B.E., Casassa, G., Cobos, G., Dávila, L.R., Delgado Granados, H., Demuth, M.N., Espizua, L., Fischer, A., Fujita, K., Gadek, B., Ghazanfar, A., Hagen, J.O., Holmlund, P., Karimi, N., Li, Z., Pelto, M., Pitte, P., Popovnin, V.V., Portocarrero, C.A., Prinz, R., Sangewar, C.V., Severskiy, I., Sigurdsson, O., Soruco, A., Usubaliev, R., Vincent, C. 2015. Historically unprecedented global glacier decline in the early 21 st century. Journal of Glaciology 61 (228), 745-761. http://doi.org/10.3189/2015JoG15J017. 